\title{
PENGARUH NAA DAN BAP TERHADAP PERTUMBUHAN CIPLUKAN (Physalis angulate L.) SECARA IN-VITRO
}

\section{INFLUENCE OF NAA AND BAP ON THE GROWTH CIPLUKAN (Physalis angulate L.) IN IN-VITRO}

\author{
Amri Assidiqi, Hasan Basri Jumin, Ernita \\ Jurusan Agroteknologi, Fakultas Pertanian, Universitas Islam Riau \\ Jalan Kaharuddin Nasution No. 113, Marpoyan, Pekanbaru, Riau 28284 \\ Email : amrie.assidiqi@student.uir.ac.id \\ [Diterima: November 2018; Disetujui: Desember 2018]
}

\begin{abstract}
The purpose of this study was to determine the interactions and main effects of NAA and BAP hormones on the growth of Ciplukan (Physalis angulata L.). The design used in this study is a complete random design (CRD) which consists of two factors. The first factor is N (NAA) which consists of 4 levels, namely: without treatment, $0.1,1$, and $10 \mathrm{mg} / 1$ while the second factor is B (BAP) consisting of 4 levels, namely: without treatment, $0.1,1$ and $10 \mathrm{mg} / 1$. The parameters observed were the percentage of hypocotyl explants forming callus, the age of callus appearing, the number of shoots, and the percentage of hypocotyl explants forming roots. The observational data is then statistically analyzed, if the F count is greater than the F table then proceed with the BNJ test at the 5\% level. The results showed that the interaction of NAA and BAP gave a significant effect on the age of callus with the best treatment was the administration of $0.1 \mathrm{mg} / 1 \mathrm{NAA}$ and $\mathrm{mg} / 1 \mathrm{BAP} 1$ (N1B2). The main effect of NAA was significantly on the age of callus with the best treatment of 1 mg / 1 NAA (N2). The main effect of BAP was significantly on the age of callus with the best treatment $1 \mathrm{mg} / 1$ BAP (B2) and the percentage of hypocotyl explants forming roots with the best treatment without BAP administration (B0).
\end{abstract}

Keywords: Ciplukan, NAA, BAP

\begin{abstract}
ABSTRAK
Tujuan penelitian ini adalah untuk mengetahui interaksi dan pengaruh utama hormon NAA dan BAP terhadap pertumbuhan tanaman ciplukan (Physalis angulata L.). Rancangan yang digunakan dalam penelitian ini adalah rancangan acak lengkap (RAL) yang terdiri dari dua faktor. Faktor pertama adalah N (NAA) yang terdiri dari 4 taraf yaitu: tanpa perlakuan, 0,1, 1, dan $10 \mathrm{mg} / 1$ sedangkan faktor kedua adalah B (BAP) yang terdiri dari 4 taraf yaitu: tanpa perlakuan, 0,1, 1, dan $10 \mathrm{mg} / \mathrm{l}$. Parameter yang diamati adalah persentase eksplan hipokotil membentuk kalus, umur muncul kalus, jumlah tunas dan persentase eksplan hipokotil membentuk akar. Data hasil pengamatan kemudian dianalisis secara statistic, jika $\mathrm{F}$ hitung lebih besar dari $\mathrm{F}$ tabel maka dilanjutkan dengan uji BNJ pada taraf 5\%. Hasil penelitian menunjukkan bahwa secara interaksi NAA dan BAP memberikan berpengaruh nyata terhadap umur mucul kalus dengan perlakuan terbaiknya adalan pemberian $0,1 \mathrm{mg} / \mathrm{l}$ NAA dan $\mathrm{mg} / \mathrm{l}$ BAP 1 (N1B2). Pengaruh utama NAA nyata terhadap umur muncul kalus dengan perlakuan terbaik $1 \mathrm{mg} / \mathrm{l}$ NAA (N2). Pengaruh utama BAP nyata terhadap umur muncul kalus dengan perlakuan terbaik $1 \mathrm{mg} / \mathrm{l}$ BAP (B2) dan persentase eksplan hipokotil membentuk akar dengan perlakuan terbaik tanpa pemberian BAP (B0).
\end{abstract}

Kata Kunci: Ciplukan, $N A A, B A P$ 


\section{PENDAHULUAN}

Tanaman ciplukan (Physalis angulata L.) merupakan tumbuhan liar yang tumbuh subur di daratan rendah sampai pada ketinggian 1.550 meter dari permukaan laut, tanaman ini dapat ditemukan di tanah tegalan, atau sawah kering. Tumbuhan ini adalah tumbuhan asli Amerika yang dapat ditemukan disemua Negara yang beriklim tropis terutama Afrika, Asia dan Amerika (Anonim,, 2010).

Tanaman ini memiliki banyak manfaat terutama dalam bidang obat-obatan, kandungan kimia ciplukan antara lain Fisalin B, Fisalin D, Fisalin F, Withangulatin A, protein, minyak lemak, asam palmitat, asam stearat, alkaloid, glokosida flavonid dan saponin. Secara spesifik glukosida flavonid dalam ciplukan terbukti dapat digunakan sebagai obat diabetes melitus (Januario dkk. 2002).

Pada umumnya masyarakat mengenal tanaman ciplukan sebagai tanaman liar yang hidup di daerah lembab. Saat ini, di Indonesia tanaman ini sangat jarang dibudidayakan secara komersial. Adapun faktor yang menyebabkan tanaman ini sangat jarang dibudidayakan ialah karena kurangnya kesadaran masyarakat tentang manfaat dari tanaman ciplukan dan menganggap bahwa tanaman ini hanya sebagai tanaman pengganggu tanaman budidaya sehingga banyak orang yang membasmi tanaman ini dengan herbisida pada saat bersamaan dengan pembasmian gulma lainnya.

Dalam rangka penyediaan tanaman ciplukan untuk bahan obat, langkah perbanyakan tanaman ciplukan merupakan hal yang harus dilakukan dengan metode budidaya dan umur tanaman, sehingga usaha budidaya dan kontinuitas tanaman obat menghasilkan kestabilan mutu atau kualitas bahan tanaman yang terstandarisasi berupa benih atau bibit tanaman obat yang mutu genetiknya baik. Perlu dilakukan upaya untuk memperbaiki mutu benih atau bibit ciplukan dengan cara perbanyakan menggunakan teknik kiltur jaringan (in-vitro).

Kultur jaringan merupakan teknik perbanyakan tanaman dengan cara mengisolasi bagian tanaman seperti daun, mata tunas, serta menumbuhkan bagian-bagian tersebut dalam media buatan secara aseptik yang kaya nutrisi dan zat pengatur tumbuh dalam wadah tertutup yang tembus cahaya sehingga bagian tanaman dapat memperbanyak diri dan beregenerasi menjadi tanaman lengkap. Prinsip utama dari teknik kultur jaringan adalah perbanyakan tanaman dengan menggunakan bagian vegetatif tanaman menggunakan media buatan yang dilakukan di tempat steril. Bagian vegetatif hipokotil merupakan bagian tanaman hasil dari perkecambahan biji yang memilik potensi untuk dijadikan sebagain bahan eksplan.

Keberhasilan untuk menghasilkan induksi kalus, tunas dan akar ditentukan oleh konsentrasi zat pengatur tumbuh yang ditambahkan pada media. Zat pengatur tumbuh merupakan senyawa organik bukan hara, yang dalam jumlah sedikit dapat mendukung, menghambat dan dapat mengubah proses fisiologi tumbuhan. Fungsi ZPT tersebut adalah untuk merangsang pertumbuhan morfogenesis dalam bentuk sel, jaringan dan organ.

Zat pengatur tumbuh (ZPT) merupakan komponen penting dalam media tumbuh. Zat pengatur tumbuh digolongkan dalam beberapa jenis yaitu auksin, sitokinin,, giberelin, etilen dan asababsisi. Namun dalam kultur jaringan yang sering digunakan adalah golongan auksin dan sitokinin. Diantaranya Naphatalene Acetic Acid (NAA) dan Benzil Amino Purin (BAP). Pemilihan NAA dan BAP lebih stabil dibandingkan yang lainnya (Harjadi, 2009).

\section{BAHAN DAN METODE}

Penelitian ini telah dilaksanakan di Laboratorium Bioteknologi Fakultas Pertanian Universitas Islam Riau, Jalan Kaharuddin Nasution Km 11, Kelurahan Air Dingin, Kecamatan Bukit Raya, Kota Pekanbaru. Penelitian dilaksanakan selama 3 bulan, mulai bulan Juni sampai bulan September 2018.

Bahan yang digunakan dalam penelitian ini adalah biji ciplukan, media MS, zat pengatur tumbuh NAA dan BAP, agar-agar, glukosa, aquades, detregen, byclean, alkohol, aluminium foil, kertas label, tween 20, karet gelang, plastik tahan panas dan tissue. Alat yang digunakan dalam penelitian ini adalah laminar air flow cabinet, autoclave, rak kultur, lemari pendingin, tabung reaksi, pipet akursi, timbangan, $\mathrm{pH}$ meter, lampu spritus, panci, botol kultur, lampu ultra violet, braker gelas, erlemeyer, gelas ukur, mikro pipet, handsprayer, scapel, cawan petri, gunting, kamera, pinset, penggaris dan alat tulis. 
Penelitian ini menggunakan Rancang Acak Lengkap (RAL) faktorial yang terdiri dari 2 faktor. Faktor pertama adalah NAA (N) terdiri dari 4 taraf yaitu tanpa pemberian NAA, 0,1 $\mathrm{mg} / \mathrm{l}, 1 \mathrm{mg} / \mathrm{l}$ dan $10 \mathrm{mg} / \mathrm{l}$, sedangkan faktor kedua adalah BAP (B) terdiri dari 4 taraf yaitu tanpa pemberian BAP, $0,1 \mathrm{mg} / \mathrm{l}, 1 \mathrm{mg} / \mathrm{l}$ dan 10 $\mathrm{mg} / \mathrm{l}$ sehingga didapat 16 kombinasi perlakuan. Setiap kombinasi perlakuan diulang sebanyak 3 kali sehingga total keseluruhan 48 satuan percobaan. Setiap botol penelitian terdiri dari 2 eksplan, dimana kedua ekspalan tersebut dijadikan sebagai sampel.

\section{Persentase Eksplan Hipokotil Membentuk Kalus}

Berdasarkan hasil sidik ragam untuk parameter persentase eksplan hipokotil membentuk kalus tanaman ciplukan dengan pemberian NAA dan BAP menunjukkan bahwa interaksi kedua perlakuan tidak memberikan pengaruh nyata terhadap persentase membentuk kalus, demikian pula pada pengaruh utama konsentrasi NAA dan BAP terhadap persentase membentuk kalus. Rerata persentase membentuk kalus tanaman ciplukan dapat dilihat pada Tabel 1.

\section{HASIL DAN PEMBAHASAN}

Tabel 1. Rerata persentase eksplan hipokotil membentuk kalus dengan pemberian NAA dan BAP

\begin{tabular}{lrrrrr}
\hline \multirow{2}{*}{$\begin{array}{c}\text { Konsentrasi NAA } \\
\text { (mg/l) }\end{array}$} & \multicolumn{3}{c}{ Konsentrasi BAP (mg/l) } & \multirow{2}{*}{ Rerata } \\
\cline { 2 - 5 } & B0 $(0)$ & B1 $(0,1)$ & B2 $(1)$ & B3 (10) & 87,50 \\
\hline N0 (0) & 100,00 & 100,00 & 100,00 & 83,33 & 91,67 \\
N1 (0,1) & 100,00 & 83,33 & 100,00 & 100,00 & 100,00 \\
N2 (1) & 100,00 & 100,00 & 100,00 & 100,00 & 91,67 \\
N3 (10) & 100,00 & 83,33 & 83,33 & 100,00 & \\
\hline \multicolumn{1}{c}{ Rerata } & 87,50 & 91,67 & 95,83 & 95,83 & \\
\hline KK $=15,10 \%$ & & &
\end{tabular}

Angka-angka pada baris dan kolom yang diikuti oleh huruf kecil yang sama tidak berbeda nyata menurut Uji lanjut BNJ pada taraf $5 \%$

Dari tabel di atas terlihat bahwa secara interaksi pemberian konsentrasi NAA dan BAP pada eksplan ciplukan (Physalis angulata L.) tidak memberi pengaruh yang nyata terhadap persentase membentuk kalus. Artinya tidak ada perbedaan pemberian konsentrasi tersebut dan dalam angka perbedaannya tidak terlalu banyak, hanya ada 2 perbedaan, yaitu: $100 \%$ dan $83,33 \%$. Dari data rerata diatas pada pemberian konsentrasi secara interaksi yang lebih tinggi yaitu $100 \%$ dan yang paling rendah yaitu $83,33 \%$. Secara tunggal NAA Persentase paling tinggi yaitu $100 \%(\mathrm{~N} 2)$ dan persentase terendah yaitu 91,67\% (N3). Secara tunggal pemberian konsentrasi BAP Persentase paling tinggi yaitu $100,00 \%$ (tanpa pemberian BAP) dan persentase terendah yaitu 91,67\% (B1).

Kalus dengan persentase terendah terdapat pada perlakuan N0B0, hal ini disebabkan karena pada perlakuan media tidak dilakukan pemberian konsentrasi zat pengatur tumbuh yang menunjang pertumbuhan kalus pada eksplan ciplukan. Eksplan ciplukan dapat tumbuh dengan baik dengan pemberian ZPT NAA dan BAP 0-10 mg/l media.

Penggunaan bagian hipokotil dalam kultur jaringan memang sangat optimal jika bertujuan untuk mendapatkan kalus. Hal ini seperti yang dijelaskan oleh Hayati et al (2010) dalam Mayariza (2015) kalus yang optimal dihasilkam dari hipokotil yang ditumbuhkan pada media dengan pemberian kombinasi konsentrasi BAP 0 ppm dan NAA $2 \mathrm{ppm}$. Selain itu dalam penelitian Sukamto (2003) juga membuktikan bahwa hipokotil wiep berhasil membentuk kalus $100 \%$ dengan penambahan ZPT $\mathrm{BA} \quad 1 \mathrm{mg} / \mathrm{l}$ maupun kombinasi BA (1-2) $\mathrm{mg} / \mathrm{l}$ dengan NAA $0,5 \mathrm{mg} / \mathrm{l}$ atau 2,4-D 0,5 mg/l.

\section{Umur Muncul Kalus}

Berdasarkan hasil sidik ragam untuk parameter umur muncul kalus tanaman ciplukan dengan pemberian NAA dan BAP menunjukkan bahwa interaksi kedua perlakuan memberikan pengaruh nyata terhadap umur membentuk kalus, demikian juga pengaruh 
utama dari kedua perlakuan konsentrasi NAA dan BAP. Rerata umur muncul kalus tanaman ciplukan setelah di uji lanjut BNJ pada taraf $5 \%$ dapat dilihat pada Tabel 2.

Tabel 2. Rerata umur muncul kalus eksplan hipokotil dengan pemberian NAA dan BAP

\begin{tabular}{|c|c|c|c|c|c|}
\hline \multirow{2}{*}{$\begin{array}{c}\text { Konsentrasi NAA } \\
(\mathrm{mg} / \mathrm{l})\end{array}$} & \multicolumn{4}{|c|}{ Konsentrasi BAP (mg/l) } & \multirow[b]{2}{*}{ Rerata } \\
\hline & B0 (0) & B1 $(0,1)$ & B2 (1) & B3 (10) & \\
\hline N0 (0) & $8,33 \mathrm{~cd}$ & $8,00 \mathrm{~cd}$ & 7,00 a-d & $7,33 \mathrm{bcd}$ & $7,67 \mathrm{~b}$ \\
\hline $\mathrm{N} 1(0,1)$ & 7,00 a-d & $8,67 \mathrm{~d}$ & $4,33 \mathrm{a}$ & 6,67 a-d & $6,67 \mathrm{a}$ \\
\hline $\mathrm{N} 2(1)$ & $6,67 \mathrm{a}-\mathrm{d}$ & $5,00 \mathrm{ab}$ & $6,33 \mathrm{a}-\mathrm{d}$ & $6,33 \mathrm{a}-\mathrm{d}$ & $6,08 \mathrm{a}$ \\
\hline N3 (10) & $20,33 \mathrm{f}$ & $16,67 \mathrm{e}$ & $5,67 \mathrm{abc}$ & $7,00 \mathrm{a}-\mathrm{d}$ & $12,24 \mathrm{c}$ \\
\hline Rerata & $10,58 \mathrm{~d}$ & $9,58 \mathrm{c}$ & $5,83 \mathrm{a}$ & $6,83 \mathrm{~b}$ & \\
\hline $\mathrm{KK}=10,84 \%$ & \multicolumn{3}{|c|}{ BNJ N \& B $=0,98$} & \multicolumn{2}{|c|}{ BNJ NB $=2.69$} \\
\hline
\end{tabular}

Data pada tabel 2 di atas menunjukkan bahwa secara pengaruh interaksi berpengaruh nyata terhadap umur muncul kalus eksplan ciplukan. Dimana umur muncul kalus tercepat terdapat pada kombinasi pelakuan NAA 0,1 $\mathrm{mg} / \mathrm{l}$ dan BAP $1 \mathrm{mg} / \mathrm{l}$ yaitu dengan rerata 4,33 hst yang tidak berbeda nyata dengan perlakuan lainnya kecuali N0B3, N0B1, N0B0, N1B1, N3B1 dan N3B0. Sementara umur muncul kalus terlama terdapat pada kombinasi perlakuan NAA $10 \mathrm{mg} / \mathrm{l}$ dan BAP $0 \mathrm{mg} / \mathrm{l}$ dengan rerata 20,33 hst yang berbeda nyata dengan perlakuan lainnya.

Kombinasi perlakuan NAA $0,1 \mathrm{mg} / \mathrm{l}$ dan BAP $1 \mathrm{mg} / \mathrm{l}$ mampu menginduksi kalus paling cepat. Hal ini diduga karena adanya interaksi yang tepat antara hormon NAA dengan BAP yang ditambahkan dalam media sehingga mengakibatkan proses fisiologis dalam eksplan dapat berlangsung secara efektif dalam memacu munculnya kalus lebih awal. Hal ini tidak jauh berbeda dengan penelitian Marthani (2016) yang menyatakan bahwa pemberian kombinasi BAP 2 ppm dan NAA 0,6 ppm memiliki rerata muncul kalus tercepat yaitu 0 HST. Serta dalam penelitian Mufidatunniswah (2017) bahwa konsentrasi 2,4-D dan BAP yaitu pada kombinasi $1 \mathrm{mg} / \mathrm{l}$ 2,4-D + 1,5 mg/l BAP merupakan konsentrasi yang paling cepat menginduksi kalus jintan hitam yakni 15 HST.

Pada penelitian ini, kombinasi NAA 10 $\mathrm{mg} / \mathrm{l}$ tanpa pemberian BAP menunjukkan induksi kalus terlama. Hal ini diduga karena dalam menginduksi kalus sitokinin yang rendah yang dikombinasikan dengan auksin yang tinggi menghambat pertumbuhan kalus, dengan kata lain eksplan mempunyai kandungan sitokinin endogen yang rendah, sehingga perlu ditambah sitokinin eksogen yang lebih banyak pada media kultur.

Adanya interaksi antara auksin dan sitokinin yang sama-sama ditambahkan pada media dengan kombinasi yang tepat akan menyebabkan eksplan hipokotil ciplukan mengalami induksi kalus. Kecepatan induksi kalus yang terjadi pada eksplan hipokotil ciplukan berbeda pada setiap perlakuannya. hal ini diduga bergantung dari respon setiap eksplan, karena selain zat pengatur tumbuh berupa auksin dan sitokinin pada media, respon sel-sel eksplan juga dipengaruhi hormon endogen dan sifat kompeten dari setiap eksplan (Santoso dan Nursandi, 2004).

\section{Jumlah Tunas}

Berdasarkan hasil sidik ragam untuk parameter jumlah tunas tanaman ciplukan dengan perlakuan NAA dan BAP menunjukkan bahwa secara interaksi maupun secara tunggal pemberian NAA dan BAP tidak memberikan pengaruh nyata terhadap jumlah tunas yang terbentuk pada eksplan hipokotil ciplukan. Rerata umur jumlah tunas dapat dilihat pada Tabel 3. 
Tabel 3. Rerata jumlah tunas eksplan hipokotil dengan pemberian NAA dan BAP.

\begin{tabular}{|c|c|c|c|c|c|}
\hline \multirow{2}{*}{$\begin{array}{c}\text { Konsentrasi NAA } \\
(\mathrm{mg} / \mathrm{l})\end{array}$} & \multicolumn{4}{|c|}{ Konsentrasi BAP $(\mathrm{mg} / \mathrm{l})$} & \multirow[b]{2}{*}{ Rerata } \\
\hline & B0 (0) & B1 $(0,1)$ & B2 (1) & B3 (10) & \\
\hline N0 (0) & $\begin{array}{c}0,71 \\
(0,00)\end{array}$ & $\begin{array}{c}0,71 \\
(0,00)\end{array}$ & $\begin{array}{c}0,71 \\
(0,00)\end{array}$ & $\begin{array}{c}0,71 \\
(0,00)\end{array}$ & 0,71 \\
\hline $\mathrm{N} 1(0,1)$ & $\begin{array}{c}0,71 \\
(0,00)\end{array}$ & $\begin{array}{c}1,22 \\
(1,00)\end{array}$ & $\begin{array}{c}0,71 \\
(0,00)\end{array}$ & $\begin{array}{c}1,25 \\
(1,67)\end{array}$ & 0,97 \\
\hline $\mathrm{N} 2(1)$ & $\begin{array}{c}0,71 \\
(0,00)\end{array}$ & $\begin{array}{c}1,60 \\
(3,67)\end{array}$ & $\begin{array}{c}1,32 \\
(2,00)\end{array}$ & $\begin{array}{c}0,71 \\
(0,00)\end{array}$ & 1,09 \\
\hline N3 (10) & $\begin{array}{c}0,71 \\
(0,00)\end{array}$ & $\begin{array}{c}0,71 \\
(0,00)\end{array}$ & $\begin{array}{c}1,47 \\
(2,00)\end{array}$ & $\begin{array}{c}2,60 \\
(8,33)\end{array}$ & 1,37 \\
\hline
\end{tabular}

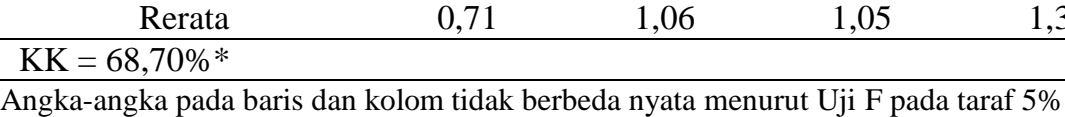

*Data telah ditransformasi $(\sqrt{x+0,5})$

Dari data tabel 3 diatas menunjukkan bahwa pembentukan tunas eksplan terbentuk pada media MS yang ditambahkan kombinasi NAA dan BAP yaitu $10 \mathrm{mg} / \mathrm{l} \mathrm{NAA} \mathrm{+} 1$ dan 10 $\mathrm{mg} / \mathrm{l}$ BAP. Pembentukan tunas juga terbentuk pada kombinas $1 \mathrm{mg} / \mathrm{l} \mathrm{NAA}+0,1 \mathrm{dan} 1 \mathrm{mg} / \mathrm{l}$ BAP. Tunas juga terbentuk pada media MS yang ditambahkan kombinasi NAA dan BAP pada konsentrasi yang sama yaitu $0,1 \mathrm{mg} / \mathrm{l}$. Perlakuan dengan penambahan $10 \mathrm{mg} / \mathrm{l} \mathrm{NAA} \mathrm{+}$ $10 \mathrm{mg} / \mathrm{l} \mathrm{BAP}$ (N3B3) merupakan konsentrasi yang paling banyak menghasilkan tunas yakni 2,60 buah. Pada perlakuan ini terlihat bakwa eksplan hipokotil ciplukan memberikan respon terhadap jumlah tunas, sedangkan sebagian besar pada perlakuan lainnya tidak memperlihatkan adanya pertumbuhan tunas. Hal ini diduga eksplan hipokotil kurang bersifat meristematik sehingga lebih sulit dalam pembentukan tunas.

Menurut Akbar et al (2017) belum mampunya eksplan dalam membentuk tunas dikarenakan: pertama eksplan epikotil dan kotiledon lebih bersifat meristematik dibandingkan eksplan hipokotil dan radikula sehingga lebih mudah dalam proses pembelahan sel dan pembentukan tunas. Kedua, eksplan hipokotil dan radikula kekurangan cadangan makanan, sehingga eksplan hanya mengandalkan penyerapan nutrisi hara dari media tumbuh saja tanpa adanya pembentukan tunas.

Hasil penelitian Akbar et al (2017) menjelaskan bahwa eksplan ruas merupakan eksplan yang terbaik dalam pembentukan tunas, sedang kan eksplan hipokotil merupakan eksplan yang terbaik untuk membentuk kalus.

\section{Persentase Eksplan Hipokotil Membentuk Akar}

Berdasarkan hasil sidik ragam untuk parameter persentase membentuk akar tanaman ciplukan dengan perlakuan NAA dan BAP menunjukkan bahwa secara interaksi kedua perlakuan tidak memberikan pengaruh yang nyata terhadap persentase membentuk akar begitu juga dengan pengaruh utama NAA. Sedangkan pengaruh utama BAP memberi pengaruh nyata terhadap persentase membentuk akar. Rerata persentase membentuk akar setelah diuji BNJ pada taraf 5\% dapat dilihat pada Tabel 4.

Dari table 4 menunjukkan perlakuan utama BAP memberikan pengaruh yang nyata terhadap persentase membentuk akar pada eksplan ciplukan, dimana persentase tertinggi terdapat pada perlakuan B0 dengan rerata $88,01 \%$ dan berbeda nyata dengan perlakuan lainnya. Hal ini diduga karena didalam eksplan sudah terkandung auksin dan sitokinin endogen yang sudah cukup optimal untuk membentuk akar. Hal ini hampir sama dengan penelitian Darwati, Wulandari dan Wardatutthoyyibah (2015), perlakuan NAA terbaik dalam pertumbuhan akar pada tanaman gaharu yakni N3 (3 mg/l NAA), sedangkan perlakuan BAP terbaik yakni perlakuan B0 (0 mg/l BAP). 
Tabel 4. Rerata persentase membentuk akar eksplan hipokotil dengan pemberian NAA dan BAP.

\begin{tabular}{|c|c|c|c|c|c|}
\hline \multirow{2}{*}{$\begin{array}{c}\text { Konsentrasi NAA } \\
(\mathrm{mg} / \mathrm{l})\end{array}$} & \multicolumn{4}{|c|}{ Konsentrasi BAP (mg/l) } & \multirow[b]{2}{*}{ Rerata } \\
\hline & B0 (0) & B1 $(0,1)$ & B2 (1) & B3 (10) & \\
\hline No (0) & $\begin{array}{c}88,01 \\
(100,00)\end{array}$ & $\begin{array}{c}2,07 \\
(0,00)\end{array}$ & $\begin{array}{c}2,07 \\
(0,00)\end{array}$ & $\begin{array}{c}2,07 \\
(0,00)\end{array}$ & 23,56 \\
\hline $\mathrm{N} 1(0,1)$ & $\begin{array}{c}88,01 \\
(100,00)\end{array}$ & $\begin{array}{c}2,07 \\
(0,00)\end{array}$ & $\begin{array}{c}2,07 \\
(0,00)\end{array}$ & $\begin{array}{c}2,07 \\
(0,00)\end{array}$ & 23,56 \\
\hline $\mathrm{N} 2(1)$ & $\begin{array}{c}88,01 \\
(100,00)\end{array}$ & $\begin{array}{c}2,07 \\
(0,00)\end{array}$ & $\begin{array}{c}2,07 \\
(0,00)\end{array}$ & $\begin{array}{c}2,07 \\
(0,00)\end{array}$ & 23,56 \\
\hline N3 (10) & $\begin{array}{c}88,01 \\
(100,00)\end{array}$ & $\begin{array}{c}2,07 \\
(0,00)\end{array}$ & $\begin{array}{c}2,07 \\
(0,00)\end{array}$ & $\begin{array}{c}16,38 \\
(16,67)\end{array}$ & 27,13 \\
\hline Rerata & $88,01 \mathrm{a}$ & $2,07 \mathrm{~b}$ & $2,07 \mathrm{~b}$ & $5,65 \mathrm{~b}$ & \\
\hline
\end{tabular}

$\mathrm{KK}=25,34 \% * \quad \mathrm{BNJ} \mathrm{B}=6,85$

Angka-angka pada baris dan kolom yang diikuti oleh huruf kecil yang sama tidak berbeda nyata menurut Uji lanjut BNJ pada taraf 5\%. *Data telah ditransformasi Arcsin

Pembentukan akar terjadi karena adanya perbandingan konsentrasi sitokinin yang lebih rendah dari pada auksin. Seperti yang telah dijelaskan Suryowinoto (1996) dalam Rozalina (2016) mengatakan apabila konsentrasi auksin lebih tinggi dari konsentrasi sitokinin maka akan membentuk akar saja, tetapi apabila konsentrasi auksin dan sitokinin seimbang dapat membentuk akar.

\section{KESIMPULAN DAN SARAN}

\section{Kesimpulan}

Berdasarkan hasil penelitian dapat diambil kesimpulan bahwa:

1. Interaksi pemberian NAA dan BAP memberikan pengaruh nyata terhadap umur muncul kalus. Perlakuan terbaik terdapat pada N1B2 $(0,1 \mathrm{mg} / \mathrm{l}$ NAA dan $1 \mathrm{mg} / \mathrm{l}$ BAP).

2. Pengaruh utama NAA nyata terhadap umur muncul kalus dengan perlakuan terbaik pada perlakuan $\mathrm{N} 1(0,1 \mathrm{mg} / \mathrm{l})$.

3. Pengaruh utama BAP nyata terhadap umur muncul kalus dengan perlakuan terbaik pada perlakuan B2 (1 mg/l ) dan persentase membentuk akar dengan perlakuan terbaik pada perlakuan B0 (tanpa pemberian BAP)

\section{Saran}

Dari hasil penelitian, untuk penelitian selanjutnya dalam kultur jaringan ciplukan perbanyakan dari hipokotil untuk mendapatkan kalus dapat disarankan menggunakan konsentrasi NAA dan BAP dibawah $10 \mathrm{mg} / \mathrm{l}$

\section{DAFTAR PUSTAKA}

Akbar, A., Farida, E., Indrioko, S.dan Herawan, T. 2017. Induksi Tunas, Multiplikasi dan Perakaran Gyrinops versteegii (Gilg.) Domke Secara In-Vitro. Jurnal Pemuliaan Tanaman. 11(1): 155 - 168.

Anonim. 2010. Ceplukan (Physalis angulata). http://tumbuhanektum.blogspot. co.id/ 2011/12/ciplukan-physalis-angulata. html. Diakses pada tanggal 3 Januari 2018.

Harjadi. 2009. Zat Pengatur Tumbuh Pengenalan dan Petunjuk Penggunaan Pada Tanaman. Penebar Swadaya. Jakarta.

Januario, Filho, Petro, Kasima, Sato dan Franca. 2000. Anti Mikrobakterial Phisalns from Phisalis angulata L. (Solanaceae) Phitoterapy. 16 (5): $445-$ 448.

Marthani,K,A., Anggraito, Y,U. dan Rahayu, E. 2016. Kologenesis Eksplan Setengah Biji Koro Benguk (Mucuna pririens L.) secara In-Vitro Menggunakan BAP dan NAA. Fakultas Matematika dan Ilmu Pengetahuan Alam. Universitas Negeri Semarang. Life Science. 5(1): 72-78.

Mayariza, D. 2015. Uji Konsentrasi Kinetin dan NAA Terhadap Pertumbuhan Eksplan Biji Manggis (Garcinia mangostana L) Secara In-Vitro. Skripsi. Fakultas Pertanian. Universitas Islam Riau. Pekanbaru. 
Mufidatunniswah, S. 2017. Induksi Kalus Embriogenik Jintan Hitam (Nigella sativa L.) dengan Kombinasi 2,4Dikhlorofenoksiasetat (2,4-D) dan 6Benzyl Amino Purine (BAP) Secara InVitro. Skripsi. Fakultas Sains dan Teknilogi. Universitas Islam Negeri Maulana Malik Ibrahim. Malang.

Rozalina. 2016. Uji Pemberian NAA dan BAP Terhadap Pertumbuhan Jeruk Kasturi (Citrus mitis) Secara In-Vitro. Skripsi. Fakultas Pertanian. Universitas Islam Riau. Pekanbaru.

Santoso, U dan Nursandi, F, 2004. Kultur Jaringan Tanaman. UMM Press. Malang.

Sukamto, L, A. 2003. Perbanyakan Tanaman Wiep (Grevillea papuana) Secara Kultur Jaringan. Bidang Botani. Puslit BiologiLIPI. Bogor. 6(5) : 685-689. 
